\title{
PELACAKAN LOKASI MOBIL MENGGUNAKAN SMS GATEWAY SIM 800 BERBASIS ATMEGA 2560
}

\author{
Amir Hamzah ${ }^{1}$, Suka Aditia ${ }^{2}$ \\ ${ }^{1,2}$ Universitas Tama Jagakarsa \\ Jl. TB Simatupang no 152 Tanjung Barat Jakarta Selatan 12530 \\ e-mail : amirhamzah@ @agakarsa.ac.id ${ }^{1}$
}

\begin{abstract}
ABSTRAK
Pelacakan Lokasi Mobil Menggunakan Sms Gateway Sim 800 Berbasisi ATMega 2560 dan Ditampilkan dengan Smartphone adalah sebuah alat peringatan saat kendaraan dicuri. Alat ini bertujuan untuk memberikan informasi kendaraan yang telah hilang dengan mengirimkan lokasi koordinat kendaraan mengunakan SMS dan dapat ditampilkan dengan aplikasi Google maps. yaitu:(1) Rangkaian sistem minimum mikro kontroler Atmega 2560 dalam modul arduino uno (42) Smartphone, (3)serta aplikasi Google maps yang sudah ada pada smartphone. Pembuatan perangkat lunak (Software) alat ini menggunakan bahasa pemrograman C. Hasil pengujian yang dilakukan, diketahui bahwa unjuk kerja Perancangan Sistem Keamanan Untuk Mengetahui Posisi Kendaraan yang hilang Berbasis sms dan Ditampilkan dengan Smartphone dengan hasil pengujian keseluruhan alat dapat menampilkan data informasi sesuai dengan yang diharapkan yaitu sebagai peringatan saat kendaraan dicuri dan mengirimkan lokasi koordinat kendaraan ke smartphone user,kemudian untuk mengetahui posisi kendaraan yang hilang user cukup membuka sms dan perintah tersebut akan memanggil aplikasi Google maps. Kesimpulan yang didapat dari alat ini adalah alat sudah dapat bekerja dengan baik.
\end{abstract}

Kata kunci : SMS Gateway Sim 800, ATMEGA 2560, Smartphone, SMS.

\begin{abstract}
Car Location Tracking Using the ATMega Sim 800-Based ATMega 2560 and Displayed with a Smartphone is a warning tool when a vehicle is stolen. This tool aims to provide vehicle information that has been lost by sending the location of the vehicle coordinates using SMS and can be displayed with the Google maps application. namely: (1) Atmega 2560 minimum micro controller system circuit in the arduino uno module (42) Smartphone, (3) as well as the Google maps application that is already on the smartphone. Making software (Software) this tool uses the C programming language. The results of tests conducted, it is known that the performance of the Design of Security Systems To Know the Position of the Missing Vehicle Based on SMS and Displayed with a Smartphone with the overall test results of the tool can display information data as expected that is as a warning when a vehicle is stolen and sends the location of the vehicle's coordinates to the user's smartphone, then to find out the position of the vehicle's missing user simply open the sms and the command will call the Google map application. The conclusion obtained from this tool is the tool can work well.
\end{abstract}

Keywords: SMS Gateway Sim 800, ATMEGA 2560, Smartphone, SMS.

\section{PENDAHULUAN}

Kasus pencurian mobil yang sering terjadi pada akhir akhir ini menuntut pemilik mobil maupun kendaraan bermotor lainnya dituntut untuk selalu waspada. Karena itu pemilik mobil dituntut untuk lebih berhati-hati serta memasang alat keamanan ekstra selain kunci kontak, khususnya saat mobil diparkir dan saat akan ditinggal pergi oleh pemilik. Baik Mobil maupun barang yang berharga yang terletak didalam mobil sering menjadi target incaran para pencuri yang menimbulkan keresahan juga kerugian materi yang tidak sedikit. Untuk mengatisipasi hal ini salah satu alat keamanan mobil saat diparkir adalah berupa alarm dan remote kontrol. Pelacakan mobil (Riyan, Andie, \& Amin, 2019) 
IN F ORMA TIK

Jurnal Informatika, Manajemen dan Komputer, Vol.11 No.2, Desember 2019

eISSN : 2580-3042

pISSN : 1979-069

Dengan permasalahan yang ada, maka pada penelitian ini dibahas mengenai perancangan ataupun merancang sebuah alat yang digunakan sebagai perancangan software sistem monitoring keamanan mobil menggunakan Sms gateway(Goel, Shah, \& Qadeer, 2011) sim 800 berbasis Android (Zaman \& Taufiqurrohman, 2018) Atmega 2560, atmega(Rəduca et al., 2016) berikut uraian dalam pembuatan perangkat.

Dengan telekomunikasi sekarang yaitu suatu teknik pengiriman atau penyampaian informasi dari suatu tempat ke tempat lain dengan menggunakan udara sebagai media transmisinya bisa mnempermudah pelacakan kendaraan. Metode yang dibuat adalah dengan sistem : information source, transmitter, channel, receiver, dan destination. Information Source (sumber informasi) merupakan pesan yang ingin disampaikan yaitu dapat berupa suara, gambar, data, kode,dan sebagainya.

\section{a. Information Source}

Penggunaan Arduino adalah suatu hardware dan sofware yang bagus untuk metode pelacakan kendaraan ini. Arduiono adalah pengendali mikro single-board yang bersifat open-source, diturunkan dari Wiring platform, dirancang untuk memudahkan penggunaan elektronik dalam berbagai bidang. Hardwarenya memiliki prosesor Atmel AVR dan softwarenya memiliki bahasa pemrograman sendiri. Saat ini Arduino sangat populer di seluruh dunia.Banyak pemula yang belajar mengenal robotika dan elektronika lewat Arduino karena mudah dipelajari. Tapi tidak hanya pemula, para hobbyist atau profesional pun ikut senang mengembangkan aplikasi elektronik menggunakan Arduino.Bahasa yang dipakai dalam Arduino bukan assembler yang relatif sulit, tetapi bahasa $\mathrm{C}$ yang disederhanakan dengan bantuan pustaka-pustaka (libraries) Arduino.

\section{b. Transmitter}

Module GSM GPRS SIM800L V2.0 adalah module QUAD BAND GSM/GPRS yang kompatibel dengan Arduino, MCS-51, STM32, AVR, dan Mikrokontroler yang compatible.Module ini Biasa di gunakan untuk voice call, SMS dan GPRS.SIM 800L V2 salah satu GSM GPRS Module yang banyak di gunakan untuk keperluan hobby dan proyek profesional.

\section{c. LM2596 Step Down Module \\ Modul ini menggunakan IC LM2596S yang merupakan Integrated Circuit (IC) untuk}

mengubah tingkatan tegangan (voltage level) arus searah / Direct Curent (DC) menjadi lebih rendah disbanding tegangan masukannya

\section{d. Limit Switch}

Adalah suatu alat yang berfungsi untuk memutuskan dan menghubungkan arus listrik pada suatu rangkaian, berdasarkan struktur mekanik dari limit switch itu sendiri.

Limit switch memiliki tiga buah terminal, yaitu : central terminal, normally close (NC) terminal, dan normally open (NO) terminal. Sesuai dengan namanya, limit switch digunakan untuk membatasi kerja dari suatu alat yang sedang beroperasi. Terminal NC,NO dan central dapat digunakan untuk memutuskan aliran listrik pada suatu rangkaian atau sebaliknya.

\section{e. Smartphone}

Smartphone adalah telepon selular dengan mikroprosesor, memori,

layar dan modem bawaan. Smartphone merupakan ponsel multimedia yang menggabungkan fungsionalitas PC dan handset sehingga menghasilkan gadget yang mewah, di mana terdapat pesan teks, kamera, pemutar music, video, game, akses email, tv digital, search engine, pengelola informasi pribadi, fitur GPS dan jasa telepon internet.

\section{f. IDE Arduino}

IDE (Integrated Development Environment) adalah sebuah perangkat lunak yang digunakan untuk mengembangkan aplikasi mikrokontroler mulai dari menuliskan source program, kompilasi, upload hasil kompilasi dan uji coba secara terminal serial

\section{g. Definisi Mikrokontroler}

Mikrokontroler adalah sebagai sebuah sistem komputer yang dibangun pada sebuah keping (chip) tunggal.

Mikrokontroler merupakan komponen utama atau biasa disebut juga sebagai otak yang berfungsi sebagai pengatur pergerakan motor (Motor Driver) dan pengolah data yang dihasilkan oleh komparator sebagai bentuk keluaran dari sensor".Mikrokontroler merupakan sebuah processor yang digunakan untuk kepentingan kontrol. Meskipun mempunyai bentuk yang jauh lebih kecil dari suatu komputer pribadi dan computer mainframe, mikrokontroler dibangun dari elemen - elemen dasar yang sama. Seperti umumnya komputer, mikrokontroler adalah alat yang mengerjakan instruksi instruksi yang diberikan kepadanya. Artinya, bagian terpenting dan utama dari suatu sistem 
IN F ORMA TIK

Jurnal Informatika, Manajemen dan Komputer, Vol.11 No.2, Desember 2019

eISSN : 2580-3042

pISSN : 1979-069

terkomputerisasi adalah program itu sendiri yang dibuat oleh seorang programmer. Program ini menginstruksikan komputer untuk melakukan tugas yang lebih kompleks yang diinginkan oleh programmer

\section{METODOLOGI PENELITIAN \\ a. Microcontroller}

Mikrocontroler sistem komputer dengan ukuran kecil dan berfungsi didalam chipnya yaitu inti prosesor, sejumlah RAM, memori program. Mikrokontroler adalah sistem proses dari elektronika digital yang berfungsi proses input dan output yang bisa ditulis program dan dihapus programnya dan mempunyai kendali. Pada mikrokonttoler bisa menekankan efisiensi dan efektifitas biayanya dimana sebuah sistem elektronik yang sebelumnya banyak memerlukan komponen-komponen pendukung seperti IC TTL dan CMOS dapat direduksi/diperkecil dan akhirnya terpusat serta dikendalikan oleh microcontroller ini. Salah satu Mikrokomtroler yang sangat baik sekarang ini yaitu papan microcontroller berbasiskan Atmega 2560. Arduino Mega 2560 untuk digunakan dalam produk dan alat yang dikendalikan secara automatis, seperti sistem kontrol mesin, remote control, mesin kantor, peralatan rumah tangga, alat berat, dan mainan. Perbedaan dengan menggunakan yang lain adalah dapat mengurangi ukuran, biaya, dan konsumsi tenaga dibandingkan dengan mendesain menggunakan mikroprosesor memori, dan alat input output yang terpisah, dapat membuat kontrol elektrik untuk berbagai proses menjadi lebih ekonomis. Sehingga sistem elektronik ini menjadi lebih ringkas dan menggunakan Atmega 2560 dalan perancangan sistem pelacak lokasi mobil akan lebaih baik dan perangkat lunak mudah dimodifikasi. Bila ada gangguan dalam sistem akan mudah ditelusuri karem sistemnya yang fleksibel. Setelah mengetahui kemudahan dalam sistem ini dibuatlah perancangannya.

\section{b. Perancangan Dan Pembuatan Alat}

1. Indentifikasi Kebutuhan Alat

Proses mempersiapkan rancang bangun pemantau lokasi mobil menggunakan sms gateway sim 800 berbasis android mega 2560 . Tujuan indentifikasi dilakukan supaya alat berkerja dengan benar, maka diperlukan alat yang dibutuhkan :

2. Langkah-langkah Pembuatan Alat

Langkah pertama adalah pintu terbuka, maka sensor magnet limit switch mulai bekerja, yaitu dengan cara alarm berbunyi, serta mengirimkan SMS yang berupa pemberitahuan bahwa alarm telah berbunyi, selanjutnya untuk mematikan alarm harus dilakukan manual, dengan cara mematikan alarm pada mobil dengan menutup pintu mobil kembali. Selanjutnya sensor GPS NEO-6M akan mengambil data lokasi terkini akan bekerja, serta mengirimkan SMS pemberitahuan bahwa kendaraan telah berubah posisi

Algoritma adalah urutan langkah-langkah logika yang menyatakan suatu tugas dalam menyelesaikan suatu masalah.

Cara kerja alat pertama adalah membaca hasil sensor yang telah dikirimkan oleh kedua sensor, yang pertama yaitu magnet reed switch, yang berfungsi sebagai pembaca ketika mobil dalam keadaan terkunci, dan sensor diaktifkan, tiba tiba pintu terbuka secara paksa, serta ada penyebab lain seperti pintu terbuka sendiri akibat dari penguncian yang kurang rapat. Yang kedua merupakan sensor yang digunakan untuk mendeteksi lokasi kendaraan, yaitu Modul GPS NEO-6M. Dapat dijelaskan bahwa sensor ini bekerja ketika alarm pintu mobil terbuka yang menyebabkan buzzer bekerja, maka secara otomatis modul GPS NEO-6M ini akan mengirimkan lokasi dimana kendaraan saat itu berada. Artinya sensor ini membaca Lokasi via maps. Selanjutnya adalah Arduino Mega 2560 yang berfungsi sebagai penerima hasil pembacaan sensor, sekaligus pemroses data yang selanjutnya akan dikirimkan datanya ke modul Sim800L. Modul SIM800L tersebut akan mengirimkan SMS (Short Message Service) berupa informasi yang telah dibaca dari salah satu maupun kedua sensor yang telah bekerja, yaitu reed switch, serta data lokasi kendaraan yang terdeteksi oleh GPS NEO-6M ke handphone user.

Alat pemanfaatan SMS (Short Message Service) untuk kontrol alarm mobil serta pendeteksi perpindahan kendaraan digunakan untuk tujuan keamanan, dimana ketika kendaraan berada jauh dari pemilik, serta dapat dengan mudah pemilik untuk mengontrol kendaraan.

Pembuatan program atau Software yang digunakan untuk membuat program adalah software yang disediakan oleh Arduino Mega itu sendiri yaitu Arduino 1.8.5.

\section{HASIL DAN PEMBAHASAN}

Dalam tahap pengujian ini akan dilakukan beberapa serangkaian tes, untuk menguji alat atau sensor yang digunakan agar berfungsi sebagai 
INFORMA TIK

Jurnal Informatika, Manajemen dan Komputer, Vol.11 No.2, Desember 2019

eISSN : 2580-3042

pISSN : 1979-069

mana mestinya. Beberapa pengujian yang dilakukan diantaranya adalah:

1. Pengukuran Power untuk semua komponen

2. Pengukuran Kinerja Sim800L \& GPS NEO $6 \mathrm{M}$

3. Pengujian sensor untuk alarm pintu (magnet reed switch).

4. Pengujian komunikasi GPS NEO 6

5. Pengujian sensor magnet ketika pintu ditutup untuk mematikan alarm

6. Pengujian Waktu Pengiriman SMS ke Pemilik Kendaraan

7. Pengujian hasil pengukuran komponen yang terhubung pada alat.

\section{a. Pengujian Power}

Dalam tahap ini, akan dilakukan terlebih dahulu pengujian terhadap input maupun output power yang akan digunakan pada alat, power dalam hal ini membahas tegangan bukan daya. Berikut adalah hasil pengukuran yang dilakukan pada komponen pada alat.

Tabel 1. Hasil Pengukuran Komponen

\begin{tabular}{|c|c|c|c|c|}
\hline $\begin{array}{c}\text { Nama } \\
\text { Komponen }\end{array}$ & $\begin{array}{c}\mathrm{V} \\
\max \end{array}$ & $\begin{array}{c}\mathrm{V} \\
\text { (on) }\end{array}$ & $\begin{array}{c}\mathrm{V} \\
\text { (off) }\end{array}$ & $\begin{array}{c}\text { Mulai } \\
\text { Bekerja }\end{array}$ \\
\hline $\begin{array}{c}\text { Limit } \\
\text { Switch }\end{array}$ & 5 & 5 & 0 & $\begin{array}{c}\text { Saat pintu } \\
\text { terbuka }\end{array}$ \\
\hline Sim 800L & 4.2 & 3.7 & 0 & $\begin{array}{c}\text { Saat data } \\
\text { akan } \\
\text { diaktifkan }\end{array}$ \\
\hline Buzzerr & 4.8 & 4.8 & 0 & $\begin{array}{c}\text { Saat } \\
\text { perintah } \\
\text { alarm } \\
\text { bekerja }\end{array}$ \\
\hline GPS Neo & 5 & 5 & 0 & $\begin{array}{c}\text { Saat data } \\
\text { lokasi } \\
\text { dibutuhkan }\end{array}$ \\
\hline Arduino & 12 & 5 & 0 & $\begin{array}{c}\text { Saat input } \\
\text { power } \\
\text { terdeteksi }\end{array}$ \\
\hline & & & &
\end{tabular}

Pengukuran semua komponen pada alat ini bertujuan untuk mengetahui batas maksimum dan minimum tegangan, agar penggunaan tegangan pada alat tidak overheat ataupun kekurangan tegangan, serta komponen dapat bekerja dengan baik sesuai yang diharapkan.

\section{b. Pengukuran kinerja Perangkat}

Pengujian ini bertujuan untuk mengetahui kinerja dan akurasi dari perangkat yang digunakan. Dalam kasus ini, dilakukan pengukuran 2 komponen, yaitu modul SIM 800L, dan GPS NEO 6M, yang data pengukurannya berupa kecepatan pengiriman SMS berdasarkan operator yang telah diuji, serta waktu pengiriman SMS tersebut. Selanjutnya pengujian akurasi GPS NEO 6M, berdasarkan akurasi lokasi yang dikirimkan alat kemudian dibandingkan dengan pengukuran manual melalui aplikasi Google maps.

Berikut merupakan tabel data hasil pengukuran kedua perangkat tersebut:

$\begin{array}{ll}\text { Operator Pengirim } & \text { : Telkomsel } \\ \text { Operator Penerima } & \text { : Telkomsel }\end{array}$

Tabel 2. Pengukuran Operator Telkomsel ke Telkomsel

\begin{tabular}{|c|c|c|}
\hline Waktu & $\begin{array}{c}\text { Lama } \\
\text { pengiriman data } \\
\text { SMS SIM 800L } \\
(\mathrm{s})\end{array}$ & $\begin{array}{c}\text { Akurasi data } \\
\text { GPS NEO 6M } \\
(\mathrm{m})\end{array}$ \\
\hline $07.00 \mathrm{AM}$ & 12.34 detik & 8 meter \\
\hline $12.30 \mathrm{PM}$ & 22.66 detik & 8 meter \\
\hline $08.00 \mathrm{PM}$ & 11.00 detik & 7 meter \\
\hline
\end{tabular}

\section{c. Pengujian komunikasi Sensor Lokasi (GPS NEO 6)}

Pada pengujian kali ini tidak membahas sinyal hanya menguji berdasarkan waktu, sensor yang digunakan adalah GPS NEO 6. ujian dilakukan dengan cara otomatis, yaitu ketika sensor pintu atau magnet switch bekerja, serta buzzer mengeluarkan suara alarm, maka GPS akan mengirimkan lokasi real kendaraan. Sensor yang dibaca oleh GPS NEO 6 adalah posisi atau koordinat kendaraan berdasarkan latitude dan longitude. Berikut merupakan tautan yang telah dikirimkan GPS NEO 6 ke Handphone user

Lokasi Kendaraan anda saat ini : https://www.google.com/maps/?q=-

6.251899,106.821940, Waktu update lokasi pada : 23/7/2019 15:20:48

Pada gambar 1 berikut ini adalah printscreen untuk hasil pembacaan sensor GPS NEO 6 yang telah bekerja: 
INFORMA TIK

Jurnal Informatika, Manajemen dan Komputer, Vol.11 No.2, Desember 2019

eISSN : 2580-3042

pISSN : 1979-069

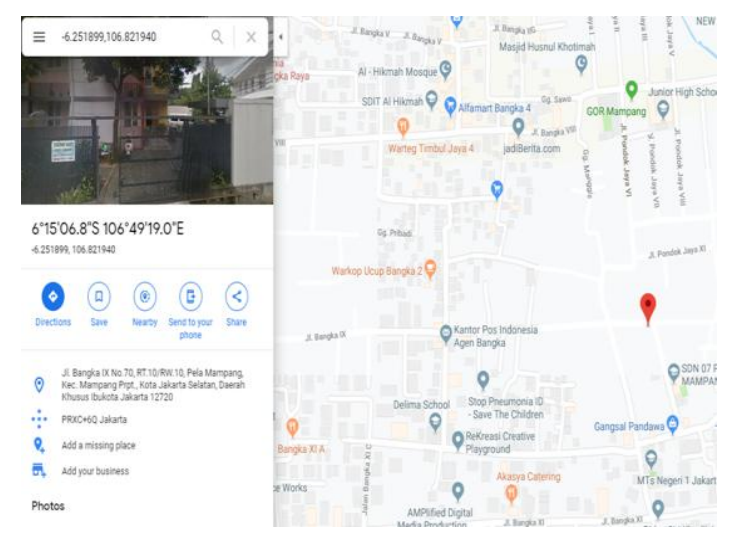

Gambar 1. Print Screen SMS Dari SIM800L

Sebagaimana Latitude adalah garis yang horisontal / mendatar. Titik 0 adalah sudut ekuator, tanda + menunjukan arah ke atas menuju kutub utara, sedangkan tanda minus di koordinat Latitude menuju ke kutub selatan, adapun Longitude merupakan garis lintang . Angka dari sudut bundar bumi horisontal. Titik diawali dari 0 ke 180 derajat, dan 0 ke-180 ke arah sebaliknya

\section{d. Pengujian Pintu Untuk Mematikan Alarm}

Pengujian ini dilakukan ketika alarm atau buzzer berbunyi ketika salah satu satu sensor pada pintu telah mendeteksi pintu terbuka. pada pengujian kali ini pintu akan ditutup kembali, apakah sensor Switch magnet dapat bekerja kembali, dengan ditandainya buzzer yang telah mati ketika pintu ditutup.

\section{e. Pengujian Waktu Pengiriman SMS ke Pemilik Rumah}

Rata-rata jangka waktu pengiriman SMS sangat tergantung pada kualitas perusahaan layanan penyedia jaringan GSM, serta kualitas jaringan ataupun sinya yang tersedia di lokasi mobil maupun lokasi user. Berdasarkan dari pengambilan data sebanyak lima kali dengan jarak yang berbeda - beda, tergantung layanan penerima yang digunakan. Jika berbeda provider, pengiriman SMS akan lebih lama jika dibandingkan dengan sesama provider. Selain itu, harus dipastikan pula pulsa yang ada di simcard dalam perangkat (SIM800L) mencukupi untuk melakukan SMS, jika pulsa tidak mencukupi, maka pengiriman SMS dipastikan gagal.

\section{f. Pengujian Hasil Pengukuran Komponen Yang Terhubung Pada Alat \\ Pengujian yang selanjutnya dilakukan adalah mengukur komponen yang terhubung,}

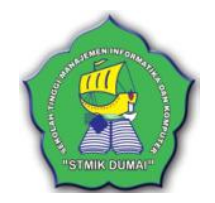

serta mengetahui tegangan dan pada angka berapa komponen atau sensor tersebut ketika mulai bekerja. Pengumpulan dan pengolahan data dari pembuatan alat Rancang Bangun Sistem Monitoring Keamanan Mobil menggunakan SMS Gateway SIM 800 Berbasis Android Mega 2560 ini dilakukan berdasarkan data pengujian yang telah didapatkan. Pengumpulan dan pengolahan data ini bertujuan untuk membuktikan hasil teori apakah sesuai dengan praktek yang dilakukan berdasarkan data percobaan yang telah didapatkan. Berdasarkan pengujian komponen yang telah dilakukan, bahwa pada switch akan mengirimkan logika 0 pada saat pintu terbuka dan tegangan $0 \mathrm{~V}$, yang berarti tidak ada tegangan masuk. Kemudian pada saat pintu tertutup switch mengirimkan logika 1 serta tegangan sebesar 4,8 volt.

Untuk komponen lain yang digunakan berbeda dari komponen komponen lainnya, yaitu tegangan saat bekerja adalah $4,8 \mathrm{v}$, serta $0 \mathrm{v}$ untuk tegangan ketika dalam keadaan off, atau tidak bekerja. Komponen tersebut diantaranya adalah buzzer dan GPS NEO 6. Untuk buzzer tegangan masuk saat bekerja adalah 3,7 - 5 volt, serta bekerja pada saat menerima perintah dari arduino, yaitu ketika sensor magnet switch mendeteksi pintu terbuka saat security mobil telah aktif. Selanjutnya adalah sensor lokasi atau GPS NEO 6.

Akan bekerja ketika pintu terbuka dan selanjutnya alarm berbunyi. Perubahan input tersebut didapatkan ketika mobil atau kendaraan yang telah dipasang sensor GPS tersebut berpindah posisi atau GPS telah mendapatkan lokasi longitude maupun longitude.

\section{KESIMPULAN}

Dari pembahasan "kontrol alarm mobil dan monitoring perpindahan kendaraan berbasis arduino" diatas, dapat disimpulkan beberapa hal sebagai berikut:

1. Sensor limit switch hanya bekerja ketika pintu dibuka.

2. Sensor Lokasi GPS NEO 6 M bekerja berdasarkan longitude $\&$ latitude.

3. Untuk mematikan alarm, pemilik kendaraan harus sms alarm off untuk mematikan alarm.

4. GPS NEO $6 \mathrm{M}$ hanya bekerja ketika sms tracking dan lokasi.

5. Tegangan pada saat switch tertutup adalah sebesar 5 volt DC

6. Tegangan masuk saat SIM 800 dan buzzer bekerja adalah sebesar 5 Volt DC 
I N F O R M A T I K A

Jurnal Informatika, Manajemen dan Komputer, Vol.11 No.2, Desember 2019

eISSN : 2580-3042

pISSN : 1979-069

7. Pembeda pada switch pada saat bekerja adalah terletak pada pin atau kaki switch di arduino.

8. Tegangan masuk pada modul SIM 800 maksimum adalah sebesar 4,5 volt.

\section{REFERENSI}

Mahajan, Nikita and Boshale, Neha. (2014). "Nikita Study of Weight Measurement System Using PIC Microcontroller". India. Vol. 4 No. 4:173

Louis, Leo. (2016). "Working Principle of Arduino and Using It As a Tool For Study and Research". India. Vol. 1. No. 2:21

Ankita, Tyagi1 dan Dr. S. Chatterjee. (2013). "Liquid Crystal Display: Environment \& Technology" India. Vol.1. No. 7:111

Lab Elektronika. (2017). "Cara Kontrol Multi LCD Karakter 16x2 Menggunakan Arduino".

http://www.labelektronika.com/2017/03/car a-kontrol-muti-lcd-karakter 16x2.html.

Sms gateway(Goel, Shah, \& Qadeer, 2011)Goel, U., Shah, K., \& Qadeer, M. A. (2011). The personal SMS gateway. 2011 IEEE 3rd International Conference on Communication Software and Networks, ICCSN 2011. https://doi.org/10.1109/ICCSN.2011.60143 45

Rəduca, E., Ungureanu-Anghel, D., Nistor, L., Haţiegan, C., Drəghici, S., Chioncel, C., ... Lolea, R. (2016). Web server with ATMEGA 2560 microcontroller. IOP Conference Series: Materials Science and Engineering. https://doi.org/10.1088/1757899X/106/1/012018

Riyan, M., Andie, A., \& Amin, M. (2019). APLIKASI RENTAL MOBIL DENGAN FITUR PELACAKAN GPS PADA CV. RAHAYU RENTAL KM 4.5 BANJARMASIN BERBASIS WEB. Technologia: Jurnal Ilmiah. https://doi.org/10.31602/tji.v10i1.1749

Zaman, M. B., \& Taufiqurrohman, M. (2018). Rancang Bangun Sistem Kontrol Dan Pemantau ROV (Remotely Operated Vehicles) Berbasis Android. Jurnal Teknik Elektro Dan Komputer TRIAC. https://doi.org/10.21107/triac.v5i1.3833

pemrograman arduiono(Kadir, 2017)Goel, U., Shah, K., \& Qadeer, M. A. (2011). The personal SMS gateway. 2011 IEEE 3rd International Conference on Communication Software and Networks, ICCSN 